\title{
The Rise of the Knowledge School and Its Relation to the Resurrection of Bildung
}

\author{
Tomas Wedin
}

\begin{abstract}
In this article the historical background to the reactivation of the concept of Bildung in the Swedish school debate during 1980s is presented. The article argues that the resurrection of this concept is intimately related to the foundation of the discourse of the Knowledge School (Kunskapsskolan), and shows how these two terms were central in school political program developed by the Knowledge Movement (Kunskapsrörelsen) in the early 1980s. The article shows how the concept of Bildung since it was resurrected not only has been highly contested, but that it was actually reactivated within the same movement that helped pave the way for the manifest economic-instrumentalist school discourse that dominates the current curriculum.
\end{abstract}

Keywords

Bildung, Kunskapsskolan, curriculum, Kunskapsrörelsen, entrepreneurship

During the past ten years, a number of books and articles have been published in Sweden that have discussed the concept Bildung. ${ }^{1}$ Many authors have suggested that the concept could serve as a counterweight to the labour market adjustments adopted by the centre-right coalition over the past eight years. The overall purpose of this article is to further nuance this debate by fulfilling three underlying aims.

First, I will show how the discourse of the Knowledge School (Kunskapsskolan) that The Liberal Party (Folkpartiet) seeks to restore emerged from a critique of the school political tendencies of the 1970s. One concrete example of this is the bill 1979/80:182 with the purpose of increasing the influence of children and their parents over the school, which culminated in a new curriculum for compulsory and secondary schools in $1980 .^{2}$ In the articulation of this discourse, the Knowledge

1 The Swedish term is bildning, but in line with English writing research, I shall refer to it as Bildung See, for example, Anders Burman and Per Sundgren, Bildning: Texter från Esaias Tegnér till Sven-Eric Liedman (Göteborg: Daidalos, 2010); Anders Burman and Per Sundgren, Svenska bildningstraditioner (Göteborg: Daidalos, 2012); Bernt Gustavsson, Bildningens väg: Tre bildningsideal i svensk arbetarrörelse 1880-1930 (Stockholm: Wahlström \& Widstrand, 1993); Bernt Gustavsson, Bildning i vår tid: Om bildningens möjligheter och villkor i det moderna samhället (Stockholm: Wahlström \& Widstrand, 1996); Gunnar Sundgren, Bildning och utbildning: En akademi för bildning? (Stockholm: Högskoleverket, 2008); Hans Ruin and Maria Sà Cavalcante Schuback, Bildning och filosofi (Stockholm: Högskoleverket, 2006).

2 The Knowledge School" has been used as a political slogan by the Liberal Party in its critique of the school policy of the Social Democrats since the first few years of the new millennium.

Tomas Wedin is a Doctoral Student of Educational Science and the Humanities at the Department of Literature, History of Ideas, and Religion, University of Gothenburg, Sweden Email:tomas.wedin@gu.se

Nordic Journal of Educational History 2015. ( ) Tomas Wedin. This is an Open Access article distributed under the terms of the Creative Commons CC-BY4.0 License (http://creativecommons.org/licenses/by/4.0/). 
Movement (Kunskapsrörelsen), within which the idea of the Knowledge School was articulated, played a prominent role. In analysing all issues of the primary means of communication of this movement, the journal Äpplet (The Apple), published between 1980 and 1991, I will show how the discourse of the Knowledge School took shape during the first half of the 1980s. When reading the journal I have searched for articles relating both to Bildung and to how the discourse of the Knowledge School surged. Contrary to what is usually claimed, I argue that it was the result of a process by which a relatively heterogeneous movement gradually narrowed and how the voices of the journal became more and more homogeneous. ${ }^{3}$ The Knowledge Movement has been given some attention in earlier studies, and $\ddot{A} p$ plet has been mentioned in that connection, but the political shift and how it may be related to Bildung has not been examined before. ${ }^{4}$

Second, I will argue that the resurrection of the concept of Bildung can be linked to the critique articulated by the Knowledge Movement. The concept was reintroduced to school administrative contexts after some decades relegated to oblivion after the Second World War in connection with the official report SOU 1992:94, which was called Skola för bildning (Schooling for Bildung). ${ }^{5}$ It was integrated into the subsequent new curriculum for upper secondary schools in the curriculum GY 2011 as well. ${ }^{6}$ Thus, the third aim of this article is to reflect on the limits of the critical potential of singular concepts in general and Bildung in particular, arguing that the concept has had a fundamentally ambiguous meaning ever since it returned in the school administrative context.

I do not disagree with the commonly held view that the increased interest in the concept of Bildung is related to the economic-instrumentalist views, in terms of which the education system has been discussed over the past few decades. ${ }^{7}$ However, in relating Bildung to the context in which it was resurrected, I believe that the concept can also be seamlessly integrated into the explicitly labour market-oriented school policy reforms (of which the new curriculum and the reformed course system are the most noteworthy examples) adopted by the centre/right coalition, The Alliance (Alliansen), since it came to power in $2006 .{ }^{8}$ One of the clearest examples of economic instrumentalism in their educational policies is the introduction of entrepreneurship as a key concept in GY 2011. I argue that the historically opposed

3 See, for example, Johanna Ringarp, "From Bildung to Entrepreneurship: Trends in Educational Policy in Sweden," Policy Futures in Education 11, no. 2 (2013), 456-64.

4 See, among others: Göran Bergström, Jämlikhet och kunskap: Debatter och reformstrategier $i$ socialdemokratisk skolpolitik (Stockholm/Stehag: Symposium Graduale, 1993); Sven-Eric Liedman "Folkpartiets skolpolitik" published 24 August 2014 in the online journal skolaochsamhälle.se; Ringarp (2013).

5 Johan Östling, Nazismens sensmoral: Svenska erfarenheter i andra världskrigets efterdyning (Stockholm: Atlantis, 2008), 165-169. SOU [Swedish Government Official Reports] is the official series of reports of committees appointed by the Swedish Government to analyse proposed fields of legislation.

6 "It is essential that schools create the best overall conditions for students' formation, thinking and development of knowledge," my translation, GY 2011, Läroplan, examensmål och gymnasiegemensamma ämnen för gymnasieskola 2011 [Curriculum for the upper secondary school], 8.

7 See Burman and Sundgren (2012), 7-8; Ringarp (2013), 456-64.

8 The Alliance is a political coalition of four liberal and right-wing parties in the Swedish parliament: The Christian Democrats, Liberal Party, New Moderate Party, and Centre Party. 
concepts of entrepreneurship and Bildung can both be related to the Knowledge Movement during its early formative years, particularly its emphasis on measurability.

\section{Bildung}

A great deal has been written about the historical transformations of the concept of Bildung. ${ }^{9}$ The many nuances that this concept contains is not, however, the focus of this article. I will leave the discussion aside and instead highlight a tension that has been the object of intense debate in Sweden in recent years. At one end of the spectrum is an ideal that posits that the education system (including both compulsory and secondary school) should focus on individual development of qualities that have not been determined in advance. There are no a priori goals. The education system is individually oriented. I refer to this approach as the open-ended educational ideal. This definition has an obvious affinity with the New Humanistic reading of Bildung, particularly the way it was defined by Wilhelm von Humboldt. ${ }^{10}$ However, since this reading of the concept is clearly related to its raison d'état, I want to avoid such a definition. ${ }^{11}$ In order to avoid misunderstanding, I will refer to the open-ended educational reading of Bildung.

The second reading of the concept emphasises reproduction (avbildning). The Swedish word avbildning consists of the prefix av ('of' or 'by') and the root bildning (Bildung), which indicates that there are predetermined ideals according to which an individual will be bildad (formed). Imagine, for example, a position whereby open-ended Bildung is the aim but the learning subject is drilled in a given canon as a means to achieve the aim. If we rely heavily on a specific canon that the student needs to pass through, avbildning may be difficult to distinguish from Bildung in practice. Theoretically it would nevertheless seem possible to distinguish between avbildning, whose aim is to transmit facts that "people ought to know" - a form of capital, something that is exchanged in a marketplace in order to gain something else - and Bildung, whose ultimate aim is to initiate - or give birth - to something that was not. Thus, it is justified to sort out the direction in which the concept of Bildung tends when it shows up in the educational policy debate. There is good reason to ask, for example, a curriculum enthusiast why (s)he believes that there should be a canon. I argue that this tension within the concept is built into "Schooling for Bildung".

The charged concept of Bildung should, as sociologist Lennart Svensson suggests in his dissertation Från bildning till utbildning (From Bildung to Education), be con-

9 See, for example, Walter Sparn, "Religiöse und theologische Aspekte der Bildungsgeschichte im Zeitalter der Aufklärung," in Handbuch der Deutschen Bildungsgeschichte. Band II. Vom späten 17. Jahrhundert bis zur Neuordnung Deutschlands um 1800, ed. Notker Hammerstein and Ulrich Herrmann (München: Beck, 2005); Joachim Heydorn, Bildungstheoretische und Pädagogische Schriften Band 1-3 (Frankfurt am Mein: Syndikat, 1980). For a good overview in Swedish with many useful notes for further reading, see Gustavsson (1996); Thomas Karlsohn, Originalitetens former (Göteborg: Daidalos, 2012).

10 See, for example, Sven Erik Nordenbo "Bildung and the Thinking of Bildung," Journal of Philosophy of Education 36, no. 3 (2002), 341-52.

11 Humboldt imagined that the ideal of Bildung was not in conflict with the state's need for a competent corps of officials; the individual's free Bildung and the state's needs are seen through the ideal of Bildung as being in harmony. Furthermore, Humboldt had primarily university students and not primary and secondary students in mind when he suggested that the ideal should be Bildung. Nordenbo (2002), 348. 
trasted with the concept of education - the two Swedish words have the same root. ${ }^{12}$ The prefix ut means 'out', indicating that this process involves interest-oriented goals that are shaped in advance by an institution that has a specific purpose in mind. Students are to be moulded in a way that serves society and the labour market. ${ }^{13}$ Thus, the term utbildning suggests that schools aim to prepare students to perform specific social functions. In contrast to the open-end educational ideal, according to which the education system is designed to take the individual into account, education aims primarily to meet the needs of society and the labour market.

\section{Why the Knowledge Movement?}

The situation for Swedish school policy changed significantly during the 1970s. Bringing clarity to the resurrection of the concept of Bildung in the school administrative field requires a focus on these changes. There were many reasons for such developments. One contributing factor was the growing critique by the political Left, which identified schools as an accomplice in the ongoing reproduction of class society. The Swedish schools were criticised for being a filter to satisfy the needs of the market. ${ }^{14}$

But criticism also came from another direction. There was increasing concern that students were learning less and lacked respect for their teachers. In response to this critique, the government ordered an inquiry entitled Internal Work of the Schools (Skolans inre arbete, SIA), which resulted in a bill in the year of $1975 .{ }^{15}$ The bill emphasised the importance of avoiding discrimination and stated that the extra resources appropriated by the government should favour students who were experiencing learning difficulties.

Thus, there was a shift from a "simple" concept of equality towards a more thorough, needs-based one. If post-war policy was to provide all students with formally equal opportunities, requirements have become more demanding such that schools must now proceed from a needs-based interpretation. Decentralisation was described as a useful tool to realise this aim. But it was also stressed that "compulsory education should use approaches and methods that are more closely linked to early childhood education,"16 that particular emphasis should "be placed on the student's proficiency," and that the school "should strive for an approach that is linked to the reality in which students find themselves." 17

These three quotes highlight some of the key issues to which a highly diverse -

12 Lennart Svensson, Från bildning till utbildning: del 1 (Göteborg: Sociologiska institutionen, Göteborgs universitet, 1978).

13 Tomas Wedin, "Ideological Continuity and Discursive Changes in the Swedish Educational System," LIR. Journal, ed. Anders Pedersen, Anton Jansson, and Hjalmar Falk, no. 3 (2013), 49-65.

14 LOVUX IV: LO:s arbetsgrupp för vuxenutbildningsfrågor, "Utbildning för arbete och demokrati: rapport till LO-kongressen 1976" (Stockholm: Prisma/Landsorganisationen i Sverige, 1976); Tomas Englund, Läroplanens och skolkunskapens politiska dimension (Göteborg: Daidalos, 2005), 268-72; Gunnar Richardson, Svensk utbildningshistoria (Lund: Studentlitteratur, 2010), 14, 138-40.

15 SOU 1974:53: Skolans arbetsmiljö: Betänkande (Stockholm: Allmänna förlaget, 1974), SOU 1974:58: Skolans arbetsmiljö: Bilagor (Stockholm: Allmänna förlaget, 1974), Skolans inre arbete: Bill 1975/76:39.

16 My original translation: "grundskolan i högre grad än för närvarande ska tillämpa arbetssätt och arbetsformer som mer knyter an till förskolepedagogiken".

17 My original translation: "läggas vid elevens färdighetsträning... i högre grad än för närvarande [bör] sträva efter ett arbetssätt som knyter an till elevernas verklighet”, Bill 1975/76, 39, 1. 
and growing - group of critics turned in the late 1970s. Despite their differences, they shared a conviction that the schools were not good enough at equipping students with knowledge and that the proposals that had been launched in SIA were not the right way to go. ${ }^{18}$ But there was no agreement on what schools should devote themselves to instead. Some people accused them of engaging in a kind of ideological positivism that prevented students from developing critical faculties. ${ }^{19}$ Among their ranks was a group (including several teachers) at KRUT, Kritisk utbildningsvetenskaplig tidskrift (Critical Educational Scientific Journal) in 1975. Donald Broady, one of the magazine's key players, belonged to this group. KRUT writers sought to identity and deconstruct the tendencies that were being reproduced in schools and elsewhere. They wanted schools to foster critical awareness and encourage practices that would neutralise the reproduction of hierarchical structures throughout society. The needs of society and the labour market must be subordinated to the free development of the individual from a progressive point of view. They argued that the goal of the education system should be to highlight structures that limited social mobility, especially by understanding how the class system was reproduced. ${ }^{20}$

Other critics argued that the role of the schools as a transmitter of knowledge was on the retreat and that this was a serious threat to both social cohesion in general and the education system in particular. One of the voices in this ever-growing group was Gunnar Fredriksson, who neatly encapsulated a central idea of this movement: "I am for schools that make you work hard." ${ }^{21}$ Scattered critical voices had been heard before, but it wasn't until 31 May 1979 that they published a proclamation initiated by Nils Elvander, a professor of political science. The following September, a number of people behind the movement started Association for Knowledge in the Schools (Föreningen för kunskap i skolan, FKS), chaired by Elvander. ${ }^{22}$ Arne Helldén and Jan Peterson, two of the leading activists, were Social Democrats, as were several of the other leaders. But there were others as well. There was constant tension between Helldén, Peterson, et al. and a number of people linked to the Communist Party. ${ }^{23}$ The movement splintered after just a few months and a faction broke off under the name of Campaign for Knowledge in the Schools (Aktion för kunskap i skolan, AKS). Helldén was a key member of this faction.

\section{Campaign for Knowledge in the Schools}

Whereas the initial FKS movement imploded for various reasons in 1982, AKS became an influential shaper of public opinion through the 1980s. Immediately breaking

18 Donald Broady, “Flera kunskaper: Det var bättre förr - tankar om kunskapsdebatten,” KRUT no. 12 (1979); Bergström (1993), 134-35. Several of the people who fall into this group consciously write "transmit," but it is not true of everyone, and assuming that the concept can be interpreted in both a larger and a more narrow perspective, I chose to write "equip" instead.

19 Sven-Eric Liedman, "Kunskaper är viktigare än moral," in Skolan som kunskapsförmedlare, ed. Jan Peterson (Stockholm: Prisma, 1979), 137-51.

20 Richardsson (2010), 156.

21 My original translation: "Jag är för pluggskolan”, Gunnar Fredriksson, ”Jag är för pluggskolan," in Skolan som kunskapsförmedlare, ed. Jan Peterson (Stockholm: Prisma, 1979), 91-96.

22 Bergström (1993), 135.

23 Including the ever-polemicising Gunnar Ohrlander, better known as Doctor Gormander, as one of the more well known, Bergström (1993), 136-37. 
away from FKS, AKS took over distribution of the journal $\ddot{A} p$ plet. ${ }^{24}$ What were the people behind $\ddot{A} p$ plet so upset about? And what did they think should be changed in the schools? Before addressing this question, it should be noted that the issues AKS concerned itself with were not simply a Swedish phenomenon; they had much in common with Mut zur Erziehung in Germany, the Back-to-Basics movement, the Commission for Excellence in Education in the United States, and les restaurateurs in France. ${ }^{25}$

Unlike FKS, which had drawn much of its membership from the Social Democrats and a sprinkling of Communists, AKS soon recruited several key people from the right side of the political spectrum. This change throughout the 1980s led to a more general shift in the nature of the issues that fuelled the movement. As the description below suggests, there is good reason to regard this change as a political shift to the right.

The initial issues of $\ddot{A} p$ plet promoted the idea that schools should transmit more knowledge. Humanistic Bildung was a core concept. Helldén emphasised the value of "classical" education in one of the very first issues. An article entitled "Fear of Bildung” (Bildningsskräck) argued:

The remarkable thing about these miscellaneous thoughts ("warm and fuzzy educational precepts") is that they are characterised by fear of Bildung. They are detached from "traditional Bildung" or "ordinary" knowledge. ${ }^{26}$

Mats Gellerfeldt, a literary critic at Svenska Dagbladet, one of the leading Swedish newspapers, wrote that "we are Social Democrats who want to restore the worker

24 The Campaign for Knowledge in the Schools (AKS) published an appeal on the crisis in Swedish schools to break the "code of silence conformism" regarding the state of the "world's most expensive schools" (Äpplet, no. 1, 1980, 3). The first issue of Äpplet was published by FKS, but the magazine was the taken over by AKS. The journal's first issue had a print run of 30,000 copies.

25 Donald Broady, "Bildningstankens krumbukter," in Svenska bildningstraditioner, ed. Anders Burman and Per Sundgren (Göteborg: Daidalos, 2012), 290. In the United States, this was nothing new; the main ideas of this criticism go much further back. In opposition to progressivism advocated by Dewey and others, a counter-movement grew. A prominent proponent of this movement, historian Arthur Bestor argued as far back as the mid-1950s for a resumption of schools that strove to impart core values instead of the anti-intellectualism that he believed characterised the schools of the time, Arthur Bestor, The Restoration of Learning: A Program for Redeeming the Unfulfilled Promise of American Education (New York: Alfred A Knopf, Inc., 1955). For a detailed discussion of how Bestor's position relates to Dewey's and other educational policy concepts, see Englund (2005); Emmamalin Larsson and Tomas Wedin, "What Knowledge is of Most Worth?" Unpublished paper (Göteborg: University of Gothenburg, 2009). The nuances of the school debate in France warrant examination. Here it is first in connection with the election of the Socialist government in 1981 (with the controversial Alain Savary, Minister of Education) and Mitterrand as president that implementation of reforms to "democratise" the school system began. Unlike what turned out to be the case in Sweden, the criticism would become more nuanced. Both the school system's former function and the reforms that were made have continued to be criticised from several different perspectives in academic debate and by the public. For a good overview of the educational criticism in France oven the last 30 years, see Franck Giol, Lectures contemporaines de la crise de l'éducation (Paris: L'Harmattan, 2009).

26 My original translation: "De utmärkande för dessa strötankar ['flumskoleidéer'] är att de präglas av bildningsskräck. De är frikopplade från traditionell bildning eller ordinär kunskap." Arne Helldén, "Bildningsskräck," Äpplet no. 1 (1980), 24-25. The idea of "warm and fuzzy education" (flumskolan) has been used ever since as an invective directed against the progressivist ideas, such as child-centred teaching, cooperation etc., that have influenced Swedish schools since the 1970s. 
movement's ideals of Bildung: We are moderates who espouse conservative traditions of Bildung." ${ }^{27}$ An article by Associate Professor Bo Magnusson entitled "Lena Hjelm-Wallén - Utilitarian Philosopher and Educational Priestess", stated that against "a flat utilitarian concept of knowledge [...] AKS suggests the classical idea of Bildung: only those who have a solid platform to build on can erect the structures that social renewal requires." ${ }^{28}$

However, Bildung is not characterised in as clear-cut a manner as indicated above. Helldén discusses two different educational ideals: "classical Bildung" from the Renaissance, and Bildung from the Enlightenment. ${ }^{29}$ In accordance with the Enlightenment ideal, human beings did not "come to earth to become a work of art (the classical ideal), but to improve the world." 30

Helldén's distinction demonstrates that two different ideals of Bildung are involved. Their many differences notwithstanding, they both strive to realise a predetermined goal. In this fundamental respect, they may both be regarded as variations of the targeted Bildung, which focuses on avbildning: The nation's level of Bildung is low because its cultural heritage has not been preserved.

Another central goal for schools as suggested by many authors is to instil order and discipline. As Helldén writes in a subsequent book on the same theme, students should be subject to "explicit expectations" and schools should have a specified social organisation - an ethos, standard and style - and "an unquestioned cultural ambition." ${ }^{31}$ The particular beliefs encompassed by the ethos are undefined. In contrast, Äpplet's first issue featured Gellerfeldt's description of his own schooling, the tone suggesting that others would do well to follow suit.

Discipline was fairly strict. Tardiness, carelessness with homework and classroom
disturbances were not tolerated. Teachers followed established standards and adhered
to the labour movement's ideals of Bildung. Knowledge is power. Morale was funda-
mental. Morale was imprinted in us: You shall do your duty. You shall do your ho-
mework. You shall be considerate of others. You shall respect your teacher. ${ }^{32}$

27 My original translation: "vi är socialdemokrater som vill återställa arbetarrörelsens bildningsideal; vi är moderater som hyllar konservativa bildningstraditioner...", Mats Gellerfeldt, Äpplet no. 1 (1980), 12.

28 My original translation: "mot det platta utilistiska kunskapsbegrepp[et]... ställer AKS en återuppväckt klassisk bildningssyn: bara den som har en stadig plattform att bygga på kan göra de tillbyggnader som samhällsförnyelsen kräver." Bo Magnusson, Äpplet, no. 1 (1980), 31-32. Lena Hjelm-Wallen was at the time Member of Parliament for the Social Democrats with particular responsibility for educational issues.

29 However, he wasn't the first person to make this distinction. A utilitarian citizen upbringing ideal and a classic elite upbringing ideal were pitted against each other in the context of the protracted upbringing debate connected to government reform in 1809, see Åke Isling, Samhällsutveckling och bildningsideal (Trelleborg: Pedagogiska skrifter, 1973), 30.

30 My original translation: "kommen till jorden för att göra sig till konstverk" [vilket skulle vara idealet enligt den "klassiska bildningstanken"] - utan för att förbättra världen..." Arne Helldén, Äpplet, no. 1 (1980), 5-8.

31 My original translation: "uttryckliga förväntningar ställs på dem [eleverna]", “etos", "standard”, "stil”, "tveklös kulturell ambition" Arne Helldén, Skola på villovägar (Linköping: Futurum, 2002), 47.

32 My original translation: "Disciplinen var ganska sträng. Det tolererades inte att vi kom för sent, slarvade med läxor eller störde undervisningen. Lärarna var noga med fasta normer... Arbetarrörelsens bildningsideal var deras. Kunskap är makt. Moral var ett nyckelord. Moral gick i arv till oss barn: Du skall göra din plikt. Du skall läsa dina läxor. Du skall visa hänsyn. Du skall visa din lärare respekt." Mats Gellerfeldt, Äpplet, no. 1 (1980), 12. 
While the ideal is fairly strict, Gellerfeldt does not argue that it should be embraced as is. Nevertheless, he presents it in a manner that is intended to appeal to the reader. The criticism of the lack of discipline and respect for teachers should be seen in light of the "softer" methods advocated by SIA. The demands for cracking down and grading conduct reappeared in various issues of the magazine, and the rhetoric grew more insistent towards the end of the decade. An article in 1987 praised Alf Svensson, leader of the Christian Democratic Party, for his demands that conduct be graded. ${ }^{33}$

The kind of society that the schools should help shape was not discussed. But issue no. 3 in 1985 offered a point-by-point programme that had been adopted by the 1984 annual meeting of AKS. The programme reflects the main concerns that the movement emphasised:

- Boldness with respect for knowledge and culture

- Schools shall provide education in the humanities and preserve the Western cultural heritage, particularly when it comes to Swedish, history, and literary history.

- Specific social norms

- Conduct grades

- Tracking in upper grades

- $\quad$ Freedom of choice through the voucher system ${ }^{34}$

Thus, the movement shifted in the 1980s. There was a change of direction in terms of the questions to be discussed. The voucher system and classroom discipline took priority. Nobody boasted that they represented ideological pluralism any longer. Furthermore, matters unrelated to the schools appeared in a number of issues towards the end of the decade.

One article in particularly helps trace the trajectory of the movement. The article is written by Krister Pettersson, "a graduate engineer and father of three," who contemplates what has become of Sweden after having spent many years abroad. High taxes, lax schools without homework or conduct grades, and gender equality committees that tell his wife and him how to organise their lives are among the problems he discusses. He ends with the following words:

We want to be free citizens in a free country-not equal subjects of the same tyranny. We believe that ours and everyone else's children should have equal rights. That is the very reason that we are in favour of more humane family and educational policies. ${ }^{35}$

33 Äpplet, no. 2-3 (1987), 9.

34 My original translation: "Frimodighet men med respekt för kunskap och kultur; Skolan skall syfta till att förmedla en humanistisk bildning och slå vakt om det västerländska kulturarvet, inte minst genom ämnena svenska, historia och litteraturhistoria; Tydliga sociala normer; Ordningsbetyg; Differentiering i högstadiet; Reell valfrihet i fråga om skolform och att skolpengen följer elever.” Äpplet, no. 3 (1985), 6.

35 My original translation: "Hon och jag vill vara fria medborgare i ett fritt land - inte undersåtar jämställda i ofrihet. Vi anser att alla andra och våra barn skall ha samma rätt. Därför är vi för en mänskligare familje- och skolpolitik." Krister Pettersson, Äpplet, no. 1 (1987), 11-12. 


\section{From the Knowledge Movement to editorials in Dagens Nyheter}

Thus, the educational discourse of the 1970s and 1980s, heavily influenced by Social Democratic ideology, found itself in a bind. It had to deal with harsh criticism from AKS and its allies, who criticised "warm and fuzzy schools" (flumskolan) as well as from KRUT and others who identified the education system as a central arena for the reproduction of class society. However, school policies did not change dramatically after the Social Democrats lost the elections of 1976 and 1979. Reforms that directly conflicted with the approach of the previous government were not enforced.

Not until the 1980s did Conservative school policy spokesman Per Unckel and party leader Ulf Adelsohn — and to a lesser extent the Liberals and Christian Democrats-begin to take strong stands based on the ideas formulated by AKS. ${ }^{36}$ An interview with Unckel in an August 1983 edition of Svenska Dagbladet suggested that the most extreme laxity had given way to a "classical ideal of Bildung." ${ }^{37}$

Motion after motion contained suggestions reminiscent of ideas expressed in Äpplet. Adelsohn emphasised the priority of proficiency goals as early as $1981 .^{38}$ English instruction and grading should start earlier, and tracking should be stressed more ${ }^{39}$ In summer 1984, he told the Swedish Parliament that the Social Democrats were pursuing a vague standard of equality while the Conservatives wanted to make sure that each student acquired genuine knowledge. ${ }^{40}$ In advocating for an education system that would be firmly anchored to the Western canon, he clearly stressed the reproduction of values. In practical terms, he underscored the importance of grades - including for discipline and conduct - earlier tracking, and a voucher system. ${ }^{41}$ Under Adelsohn's leadership, the Conservatives drifted rightward on a number of issues. The party's website states that it developed a positive alternative to its previous policies, which had been increasingly critical. ${ }^{42}$ Historian Torbjörn Nilsson's review of the party's ideological development from 1976 to 1991 reaches the same conclusion. ${ }^{43}$

The outlines of an educational policy discourse that emerged in some liberal newspapers, particularly Dagens Nyheter, in the 1990s began to appear. In her dissertation of 2006 Matilda Wiklund analyses the way that the paper's op-ed and editorial pages described and envisaged Swedish schools. ${ }^{44}$ As late as the early 1980s, Äpplet published an article entitled "Society Profits from the Lack of Knowledge: Dagens Nyheter Leads the Way." 45

36 Bergström (1993), 216.

37 Broady (2012), 289-90.

38 Motion 1983/84: 2016.

39 Motion 1983/84: 2016.

40 Parliament protocol 1983/84: 166.

41 The movement stated in Äpplet no. 4, 1985 that the Liberal Party and the Moderates were the only parties pursuing its issues.

42 http://www.moderat.se/partihistorik (2014-11-03). The website of the New Moderates states that an ideological offensive was launched during the 1970s and 1980s.

43 Torbjörn Nilsson, Moderaterna, marknaden och makten: Svensk högerpolitik under avregleringens tid, 1976-1991 (Stockholm: Södertörns högskola, 2003), 56-57.

44 Matilda Wiklund, Kunskapens fanbärare: Den goda läraren som diskursiv konstruktion på en mediearena (Örebro: Örebro universitet, 2006), 161-78.

45 My original translation: "Samhället profiterar på okunnigheten: Dagens Nyheter går i spetsen." Mats Gellerfeldt, Äpplet, no. 1-2 (1980), 10-11. 


\section{Battle over the concept of Bildung}

Criticism by AKS was a reaction to the educational policies of the 1970s, not least as a result of SIA's proposals. Another target of AKS criticism was the official government report on grades in 1977 and those who actively promoted their elimination up until the age of fourteen. ${ }^{46}$ This was the context in which the concept of Bildung returned with respect to the education system.

Mostly due to waning German influence, the concept had appeared only rarely in post-war discussions of school policy. ${ }^{47}$ Apart from Unckel, members of the educational community tended to ignore the notion of Bildung, whereas people linked to AKS frequently brought it up. But several commentators outside AKS challenged the interpretation that focused on reproduction. Broady was one of them.

His article "Om bildning och konsten att ärva" (Bildung and the art of inheriting) challenged the Bildung ideal that Unckel had promoted in the interview mentioned above. ${ }^{48}$ Inspired by fresh interpretations of the new humanistic ideal of Bildung, he argued for the concept's progressive potential. ${ }^{49}$ The interpretations offered him a bridge to the critical perspective that he and others behind KRUT thought should inform the school..$^{50}$

Pamphlets published by the National Agency for Higher Education (Universitetsoch högskoleämbetet) made it clear that the meaning and potential of Bildung were of interest elsewhere as well. ${ }^{51}$ However, neither Broady's article nor the pamphlets resonated very deeply in discussions of educational policy. The article is nevertheless worthy of particular attention since it was the first to emphasise the above distinction between avbildning and Bildung in the context of schools.

The next time school-oriented journals highlighted the term was in connection with government investigation SOU 1992:94, Skola för bildning (Schooling for Bildung). ${ }^{52}$ Broady played a central role this time as well, called in as an expert for the preliminary inquiry under Ulf P. Lundgren, professor of pedagogics. His ideas, particularly his text about Bildung, influenced the commission's proposal to a certain ex-

46 SOU 1977:09: Betygen i skolan: Ett betänkande av 1973 års betygsutredning (Stockholm: Allmänna bokförlaget, 1977). One of the most prominent critics of the grading system was the future party leader for the Social Democrats in Sweden, Mona Sahlin, who criticised the system in a radio program focusing on schools, Britt Mogård and Mona Sahlin in Skolan: Ett hett debattämne i alla tider. Swedish Radio's archive, October 3, 1978.

47 Östling (2008), 165-69. However, the concept was brought up in the more general cultural debate. Two examples: Åke Isling’s Samhällsutveckling och bildningsideal: Skolpolitiska längdsnitt och strukturskisser (Stockholm: Pedagogiska skrifter 252, 1973); Erik Hjalmar Linder, Bildning i det tjugonde seklet (Stockholm: Natur \& Kultur, 1962).

48 Donald Broady, “Om bildning och konsten att ärva," KRUT 8, no. 35-36 (1984), 4-15.

49 See, for example, Hans-Joachim Heydorn, Bildungstheoretische und Pädagogische Schriften Band 1-3 (Frankfurt am Mein: Syndikat, 1980).

$50 \mathrm{He}$ was, though, not the first to highlight the tension inherent to this concept. Sociologist Lennart Svensson makes a similar argument in his extensive study Från bildning till utbildning [From Bildung to education] for the emancipatory potential of the concept of Bildung. In this connection, he also emphasised the tension that the concept holds, Svensson (1978), 224.

51 Kenneth Abrahamsson ed. Bildningssyn och utbildningsreformer: Om behovet av bildningsmål i gymnasium och högskola (Stockholm: Liber Utbildning i samarbete med Universitets och högskoleämbetet (UḦ̈), 1984).

52 See, for example, Göte Rudvall ed. Bildning och utbildning: Texter till ett seminarium om bildning och utbildning, (Malmö: Lärarhögskolan, 1994) and Forskning om utbildning, no. 3-4 (1993). 
tent. Broady also participated in the translation of an educational inquiry by the researchers at College de France, led by the French sociologist Pierre Bourdieu (whom Broady earlier had introduced in Sweden)..$^{53}$

However, the open-ended ideal of Bildung lacked the impact for which the Commission had hoped. Goals were plentiful, not only at the system level - which Lundgren had imagined - but also at the individual level. ${ }^{54}$ The prospects for largely goal-oriented schools to adopt such an ideal were anything but good, as the intellectual historian Bernt Gustavsson has pointed out. ${ }^{55}$

On the other hand, an education system that strives to implement the avbildning ideal meshes very well with goal orientation. Another factor that influenced the gap from idea to practice was that the curriculum committee for "Schooling for Bildung" and the grading committee were unable to cooperate. Several leading supporters of the curriculum committee were very disappointed when the goal-oriented grading system was presented. ${ }^{56}$ Lundgren said in a 2006 interview that "the whole idea of managing schools based on goals was that it would be linked to evaluating the system, not individuals." 57

The goal-oriented grading system was only one of several changes to the Swedish education system. Only now, for example, was the SIA commission's proposal for greater decentraliation implemented. ${ }^{58}$ Once the proposal had been fully launchedboth through increased financial responsibility and municipal oversight of goal fulfilment-the regulatory framework for the establishment of independent schools (privately run but publicly funded) was relaxed. The changes also included the adoption of a voucher system that allowed students and parents to choose schools.

Sweden suddenly went from having one of the most centralized education systems in the world to one of the most decentralized. Of course, the SIA commission was not the only source of the reforms. Sentiment for school choice was strong in the early 1990s. The focus on individual-oriented goals was hardly limited to the educational arena. Several areas of the welfare system were subject to efficiency goals under economically inspired slogans such as new public management and social choice. Thus, more than one prominent idea from SIA (a product of criticism by the 1970s leftist school) was implemented at the same time as the centre/right government led a freedom-of-choice revolution.

The fact that the curriculum committee presented its reform proposal on the

53 As a part of his contribution to the work with Skola för bildning, Broady introduces and translates the suggestion for a change in schools put forth by the scholars at the Collège de France: Propositions pour l'enseignement de l'avenir. As for the title selection, "Schooling for Bildung", which, in the light of the above written is tempting to ascribe just Broady, none of the people involved that I have been in contact with (Berit Hornqvist, Donald Broady, Ingrid Carlgren, Ulf P. Lundgren), remember why they chose to include Bildung in the title (personal communication Nov. 8-9, 2012).

54 Donald Broady and Ulf P. Lundgren, "Hela havet stormar," Ord \& Bild, ed. Rune Romhed, no. 3-4 (2006), 12.

55 Bernt Gustavsson, Bildning $i$ vår tid: Om bildningens möjligheter och villkor $i$ det moderna samhället (Stockholm: Wahlström \& Widstrand, 1996), 255.

56 Personal communication with Ingrid Carlgren, Inger Hörnqvist and Ulf P. Lundgren, Nov. 8-9, 2012.

57 My original translation: “[...] hela idén med målstyrningen av skolan var att den skulle kopplas till utvärdering av systemet, inte till kontroll av individer." Broady and Lundgren (2006), 12.

58 Bill 1990/91: 18. 
same day as the central bank raised its prime rate to $500 \%$ was an omen of things to come. Cutbacks in the wake of the crisis limited the financial manoeuvrability of both municipalities and the government for ensuring equal education throughout the country. Since municipal spending was discretionary and there was no clear framework to monitor the changes, inequalities in the resources appropriated for individual students were inevitable. However, the simultaneous shift from equality to equivalence as an overall aim of the education system (see below) limited the conceptual change. ${ }^{59}$

Subordination of one area after another to goal-oriented thinking can be understood in light of the ideological and structural changes that Sweden began to undergo in the 1980s. By the middle of the decade, the great majority of economists in Sweden had abandoned Keynesianism and were basing their analyses on classical equilibrium theory inspired by James Buchanan, Gordon Tullock and other prominent members of the Public Choice school. ${ }^{60}$

The postulate of the rational actor, the idea of the supremacy of supply and demand, and the emphasis on individual responsibility gradually eroded the base of support for equality as a key social objective. The transition to the concept of equivalence was the manifestation of this trend in the area of education. Equivalence and the flexibility it reflects appear to be more attractive than equality in a society characterised by the rational attempt to satisfy individual preferences. According to Tomas Englund and Ann Quennerstedt, the trend was also an expression of the ideological drift towards a more responsibility-oriented form of individualism starting in the 1980 s. $^{61}$

Challenged by the rebirth of these economic doctrines, the Social Democrats could no longer avoid the fateful question of equality versus labour market reform. Simultaneously cutting the public budget, more strictly evaluating efficiency and allowing more scope for citizens to make their own choices was inconsistent with the kind of equal opportunity that SIA was looking for. Given that the government was accused of inefficiency (public choice critique) and acting like guardians (by both the Left and the Right) - not to mention the fact that demands for greater decentralisation had grown increasingly vociferous since the mid-1970s - goal-orientation and decentralisation appeared to be a decent combination.

Due to the resurrection of the ambiguous Bildung concept at the administrative level, support could be counted on from both the discipline-oriented and emancipation-oriented factions of the educational policy debate. The renaissance of Bildung also reflected the growing importance ascribed to education as a vehicle of economic

59 Bergström (1993), 219; Tomas Englund and Ann Quennerstedt, "Likvärdighetsbegreppet i svensk utbildningspolitik," in Vadå likvärdighet, ed. Ann Quennerstedt and Tomas Englund, 7-35 (Uddevalla: Daidalos 2008).

60 Agneta Hugemark, Den fängslande marknaden (Lund: Studentlitteratur, 1994).

61 Englund and Quennerstedt (2008), 22. Alongside native-grown ideas, the same laissez-faire liberal tradition gained popularity in both Europe and the United States. In 1981, Ronald Dworkin laid the foundation for an egalitarian answer to the responsibility question in his articles, "What is Equality? Part 1: Equality of Welfare" and "What is Equality? Part 2: Equality of Resources," Philosophy and Public Affairs 10, no. 3-4, 1981. The two articles gave rise to the luck-egalitarianism stream (immensely influential the analytical tradition) in the political-philosophical debate of the time. The termed was coined by Elisabeth Anderson in "What's the Point of Equality," Ethics 109, no. 2 (1999), 287-337. 
growth by augmenting human capital. ${ }^{62}$ For example, the notion of lifelong learning reappeared at the same time and has been part of the educational discourse ever since. ${ }^{63}$ The concept originally emerged in the early 1970s. The focus at that time had been on issues such as unequal access to education among the various social classes. ${ }^{64}$

When "Schooling for Bildung" was presented, the intellectual historian Crister Skoglund wrote that the resurrection of Bildung was a kind of "sugar coating for the rather bitter reforms that have been adopted." ${ }^{65}$ Considering how schools have changed since 1993, there is good reason to believe that the concept's survival in GY 2011 can also be explained in this way. From the standpoint of entrepreneurship, however, the use of Bildung in the current curriculum is certainly more than just sugar coating.

\section{Entrepreneurship}

Schools should help students develop skills and attitudes that promote entrepreneurship, enterprise and innovative thinking. As a result, they will be better prepared to start and run businesses. Entrepreneurial skills are valuable in the workplace, in the community and for advanced studies. ${ }^{66}$

The above quote is from GY 2011, the curriculum for the various types of upper secondary school education in Sweden. ${ }^{67}$ The curriculum makes it clear that entrepreneurship should inform all levels of education. This should be regarded as both an educational approach and a concrete effort to disseminate knowledge about enterprise ("entrepreneurship" on the website of the Swedish National Agency for Education, Skolverket). Eva Leffler, Ron Mahieu and others have conducted research about

62 An important contributor to the development of the idea of human capital was Gary Becker. Since he developed his theories on human capital as a fourth production factor and the "alternative cost" approach to human behaviour, i.e. the idea of homo oeconomicus, the practical importance of these ideas have gradually increased. For an accessible introduction to Becker, one of the main contributors to the development of man as homo oeconomicus, see his Nobel Lecture, available online, Gary Becker, Nobel Lecture December 9th, 1992 http://www.nobelprize.org/nobel_prizes/economic-sciences/laureates/1992/becker-lecture.pdf (accessed June 28, 2014).

63 See Magnus Dahlstedt, "I val(o)frihetens fotspår: Segregation, differentiering och två decennier av skolreformer," Pedagogisk forskning i Sverige 12, no. 1 (2007), 20-38.

64 "Strong support must be given democracy, as the only way for man to avoid becoming enslaved to machines, and the only condition compatible with the dignity which the intellectual achievements of the human race require; the concept of democracy itself must be developed, for it can no longer be limited to a minimum of juridical guarantees protecting citizens from the arbitrary exercise of power... more support must also be given to educational requirements, for there cannot... be a democratic and egalitarian relationship between classes divided by excessive inequality in education, and the aim and content of education must be recreated, to allow both for the new features of society and the new features of democracy." Edgar Faure et al., Learning to be (Paris: UNESCO, 1972), xxvi.

65 My original translation: "en sockerglasyr för de tämligen beska reformer som har genomdrivits," Crister Skoglund, "Herder och en skola för bildning," Forskning om utbildning, 3, no. 4 (1993), 28.

66 My original translation: "Skolan ska bidra till att eleverna utvecklar kunskaper och förhållningssätt som främjar entreprenörskap, företagande och innovationstänkande. Därigenom ökar elevernas möjligheter att kunna starta och driva företag. Entreprenöriella förmågor är värdefulla för arbetslivet, samhällslivet och vidare studier."

67 Because the translation of the curriculum to English does not contain a reasonable term for "bildning" and entrepreneurship is italicised in the original Swedish version, I decided to do a more precise translation myself. 
how this concept was introduced in school policy discussions.$^{68}$ Leffler's dissertation distinguishes between two entrepreneurial discourses: one narrow and one broad. The narrow discourse emphasizes the external enterprise, which can be directly linked to the economy. The broad discourse focuses on the inner enterprise, which "approaches education in general by relating it to upbringing and inner human qualities." ${ }^{\prime 6}$ Leffler and Mahieu, as well as Magnus Dahlstedt and Fredrik Hertzberg, argue that the second discourse best characterises the way that this concept has been used in Swedish discussions of educational policy. ${ }^{70}$ According to this reading, entrepreneurship is part of the school policy discourse, which has been dominated by concepts such as flexibility, adaptability and responsibility ever since the 1990 s. $^{71}$

Interpreting entrepreneurship in this way also sets the stage to accept the open-ended reading of Bildung by the emerging school. The creation of something that has not been predetermined, the core idea of such a reading, can now be interpreted in a less ambiguous fashion, consistent with the kind of internal enterprise that the entrepreneur represents. Without any pre-planning, the education system should shape individuals who will not waste their time on terms such as meaning. Not only will they think about proper (useful) things, but they will be inspired to commercialise their ideas.

Interpreted in this way, entrepreneurship becomes the thread that weaves together the open-ended ideal of Bildung with the stark realities of the education system in GY 2011. Bildung and education, the creation of something that is not predetermined, and labour market needs intertwined in entrepreneurial learning replace "warm and fuzzy" creation with productive creativity. ${ }^{72}$ This reading is similar to that which Dahlstedt and Hertzberg present in their Foucault-inspired explanation of the central role of entrepreneurship in discussions of educational policy. They argue that the introduction of the concept involves both I-technologies ("free" Bildung) and power technologies (the stark realities of the education system). ${ }^{73}$

In line with the arguments of the Knowledge Movement during the 1980s, clear inspiration from the ideal of avbildning can also be discerned in GY 2011. Belief in the value of indoctrinating students with a common curriculum to be tested in national exams jibes with the above notions of entrepreneurial learning. ${ }^{74}$ Thus, a clear distinction is drawn between evidence-based knowledge and what is to be regarded as warm and fuzzy. ${ }^{75}$ Measurability becomes the criterion, the line of demarcation

68 Eva Leffler, Företagsamma elever: Diskurser kring entreprenörskap och företagsamhet i skola (Umeå: Umeå universitet, 2006), Ron Mahieu, Agents of Change and Policies of Scale (Umeå: Umeå University, 2006).

69 My original translation: "inre företagsamheten", "vänder sig mot utbildning i allmänhet genom att relatera till fostran och mänskliga inre kvaliteter." Leffler (2006), 89.

70 Magnus Dahlstedt and Fredrik Hertzberg, "Den entreprenörskapande skolan: Styrning, subjektsskapande och entreprenörskapspedagogik," in Pedagogisk Forskning i Sverige 16, no. 3 (2011), 195; Leffler (2006), 89, 225; Mahieu (2006), 8.

71 Dahlstedt and Hertzberg (2011), 179-98.

72 Ernesto Laclau and Chantal Mouffe, Hegemony and Socialist Strategy: Towards a Radical Democratic Politics (London: Verso, 1985), 105.

73 Dahlstedt and Hertzberg (2011), 195.

74 Folkpartiet, "Frihet i globaliseringens tid," 2013 (Political Party Programme).

75 For a more profound discussion of measurability and the Knowledge School's academic ideological foundation, see Emmamalin Larsson and Tomas Wedin, "What Knowledge is of Most Worth?". Unpublished paper (Göteborg: University of Gothenburg, 2009), especially pages 13-17 and 35-36. 
that distinguishes knowledge from opinion. Anything that cannot be measured is relegated to low priority. Entrepreneurship might be considered to be the missing link in the discourse of the "mature" Knowledge Movement.

From having been introduced during a period of political turmoil characterised by a severe economic crisis and a new centre/right government, with various possible interpretations that made it particularly apt to rally around, the meaning of Bildung in GY 2011 appears to be rather narrow. What emerges is the impression of a positivist view of knowledge, according to which individuality is charged with meanings such as responsibility and productive creativity and future economic growth is the horizon within which the education system is to be understood.

The break with previous curriculum ideals is not, however, as abrupt as it might appear. Similar ideas also set limits for the upper secondary school curriculum of the 1970s, though articulated within a very different educational discourse. ${ }^{76} \mathrm{Ne}$ vertheless, a key difference between the current and previous curriculum is the blunt fashion in which the ideas of employability is presented in GY 2011, clearly illustrating the underlying political changes that have occurred over the last twenty years. Whereas the concept of Bildung as first introduced can be regarded as a compromise between forces with substantially different agendas, it is fairly restrained in its peripheral role in GY 2011. Although all of the last three curricula (1970, 1994 and 2011) have been explicitly based on the needs of the labour market, representing different forms of the same ideological horizon, GY 2011 reveals substantial discursive changes within the same horizon.

\section{Concluding remarks}

I have discussed the emergence of the Knowledge Movement and related it to the resurrection of the concept of Bildung, as well as how they are associated with the appearance of the concept of entrepreneurship in educational policy over the past ten years. A constructive question to consider in light of this discussion is what role, if any, the concept of Bildung should play in the education system of tomorrow? "Schooling for Bildung" did certainly not become what Broady, Carlgren, Lundgren and the others in the committee had hoped for. The concept itself has, however, lived on and can, in its flexibility, be actively integrated into the new curriculum as well.

This development notwithstanding, I am convinced that we have a lot to learn from it. However, as the intellectual historian Thomas Karlsohn has written with regard to the boom for Humboldt's ideas in recent years, these "[...] romantic inspirations do not teach what specific words and concepts we will use. Rather, they teach us what language we should actually speak." 77 Within a well-defined linguistic cloak and joined with actual reforms concerning the educational practices, I certainly believe that the concept of Bildung offers us a logic that is more relevant today than ever before.

Looking beyond the limited scope of this article, the text forms part of a broader project in which I aim at presenting new perspectives of the ideological shifts within

76 Wedin (2013).

77 My translation, originally: "romantiska inspirationskällor inte lär oss vilka specifika ord och begrepp vi skall använda. Snarare lär de oss vilket språk vi över huvud taget skall tala." Thomas Karlsohn, Originalitetens former (Göteborg: Daidalos, 2012), 109. 
the school system since 1970. As I have argued, I believe that the ideological and material conditions that gave birth to the Knowledge Movement are essential for our understanding of our current situation. The straw-man dichotomy of "warm and fuzzy school" vs. the "knowledge school", invented by the Knowledge Movement and later on frequently articulated by the former Swedish Minister for Education, Jan Björklund, does not seem to be a particularly clarifying distinction in itself. Those very energies that gave birth to it, on the other hand, I believe are important keys in order to understand the chain of events that have led us to the current situation.

As I have contended above, the Knowledge Movement was, but a few years after it was founded, transformed into a rather one-dimensional political force, very much in line with the school political program under the Swedish conservative party ( $\mathrm{Mo}$ deraterna) during the 1980s. But what happened with those forces that shared the initial critique of the Knowledge Movement that did not agree on the way the movement developed during the 1980s? And even if we, for the sake of the argument, assume that they all accepted the way in which the movement developed during the decade, how come that no alternative school-critical movement emerged? We have good reasons to believe that the initial critique articulated by the Knowledge Movement in fact went beyond the left-right political spectrum, and that there were more voices coming from the left that criticized the way in which the school developed. ${ }^{78}$ Addressing questions like these is crucial for a more adequate understanding of the current situation in Sweden.

78 Jan Peterson ed. Skolan som kunskapsförmedlare (Stockholm: Prisma, 1979). 


\section{References}

Abrahamsson, Kenneth ed. Bildningssyn och utbildningsreformer: Om behovet av bildningsmål i gymnasium och högskola. Stockholm: Liber Utbildning i samarbete med Universitets och högskoleämbetet (UHÄ), 1984.

Anderson, Elisabeth. "What's the Point of Equality." Ethics 109, no. 2 (1999), 287337.

Bergström, Göran. Jämlikhet och kunskap: Debatter och reformstrategier $i$ socialdemokratisk skolpolitik 1975-1990. Stockholm: Brutus Östlings förlag, 1993.

Becker, Gary. "Nobel Lecture." http://www.nobelprize.org/nobel_prizes/economicsciences/laureates/1992/becker-lecture.pdf.

Bestor, Arthur. The Restoration of Learning. A Program for Redeeming the Unfulfilled Promise of American Education. New York: Alfred A Knopf, Inc., 1955.

Broady, Donald. "Flera kunskaper: Det var bättre förr - tankar om kunskapsdebatten." KRUT no. 12 (1979).

Broady, Donald. "Bildningstankens krumbukter." In Svenska bildningstraditioner, edited by Anders Burman and Per Sundgren, 285-308. Göteborg: Daidalos, 2012.

Burman, Anders and Per Sundgren, ed. Bildning: Texter från Esaias Tegnér till Sven-Eric Liedman. Göteborg: Daidalos, 2010.

Broady, Donald. "Om bildning och konsten att ärva." KRUT 8, no. 35-36 (1984), 4-15.

Broady, Donald and Ulf P. Lundgren. "Hela havet stormar." Ord \& Bild, edited by Rune Romhed, no. 3-4, (2006), 8-19.

Dahlstedt, Magnus. "I val(o)frihetens fotspår: Segregation, differentiering och två decennier av skolreformer." Pedagogisk forskning i Sverige 12, no. 1 (2007), 20-38.

Dahlstedt, Magnus and Fredrik Hertzberg. "Den entreprenörskapande skolan: Styrning, subjektsskapande och entreprenörskapspedagogik." Pedagogisk Forskning $i$ Sverige 16, no. 3 (2011), 179-98.

Dworkin, Ronald. "What is Equality? Part 1: Equality of Welfare." Philosophy and Public Affairs 10, no. 3, (1981), 185-246.

Dworkin, Ronald "What is Equality? Part 2: Equality of Resources." Philosophy and Public Affairs 10, no. 4 (1981), 283-345.

Elvander, Nils (1979-05-31) in Dagens Nyheter.

Englund, Tomas. Läroplanens och skolkunskapens politiska dimension. Göteborg: Daidalos, 2005.

Englund, Tomas and Ann Quennerstedt. "Likvärdighetsbegreppet i svensk utbildningspolitik." In Vadå likvärdighet, edited by Ann Quennerstedt and Tomas Englund, 7-35. Uddevalla: Daidalos, 2008.

Faure, Edgar, Felipe Herrera, Abdul Razzal Kaddoura, Henri Lopes, Arthur V. Petrovsky, Majid Rahnema, and Frederick Champion Ward, Learning to be. Paris: UNESCO, 1972.

Folkpartiet, "Frihet i globaliseringens tid," 2013 (Political Party Programme).

Fredriksson, Gunnar. "Jag är för pluggskolan.” In Skolan som kunskapsförmedlare, edited by Jan Peterson, 91-96. Stockholm: Prisma, 1979.

Giol, Franck. Lectures contemporaines de la crise de l'éducation. Paris: L'Harmattan, 2009.

Gustavsson, Bernt. Bildning i vår tid: Om bildningens möjligheter och villkor $i$ det moderna samhället. Stockholm: Wahlström \& Widstrand, 1996. 
Gustavsson, Bernt. Bildningens väg: Tre bildningsideal i svensk arbetarrörelse 18801930. Stockholm: Wahlström \& Widstrand, 1993.

GY 2011, Läroplan, examensmål och gymnasiegemensamma ämnen för gymnasieskola 2011. Stockholm: Skolverket, 2011.

Helldén, Arne. Skola på villovägar. Linköping: Futurum, 2002.

Heydorn, Heinz-Joachim. Bildungstheoretische und Pädagogische Schriften Band 1-3. Frankfurt am Mein: Syndikat, 1980.

Hugemark, Agneta. Den fängslande marknaden. Lund: Studentlitteratur, 1994.

Hultqvist, Kenneth and Kenneth Petersson. "Iscensättningen av samhället som skola." In Pedagogik, edited by Jens Bjerg, 496-527. Malmö: Liber, 2000.

Isling, Åke. Samhällsutveckling och bildningsideal. Trelleborg: Pedagogiska skrifter, 1973.

Karlsohn, Thomas. Originalitetens former. Göteborg: Daidalos, 2012.

Laclau, Ernesto and Chantal Mouffe. Hegemony and Socialist Strategy: Towards a Radical Democratic Politics. London: Verso, 1985.

Larsson, Emmamalin and Tomas Wedin. "What Knowledge is of Most Worth?” Unpublished paper. Göteborg: University of Gothenburg, 2009.

Leffler, Eva. Företagsamma elever: Diskurser kring entreprenörskap och företagsamhet i skola. Umeå: Umeå universitet, 2006.

Lgr 11. Läroplan för grundskolan, förskoleklassen och fritidshemmet 2011. Stockholm: Skolverket, 2011. http://www.skolverket.se/publikationer?id=2575.

Liedman, Sven-Eric. "Kunskaper är viktigare än moral." In Skolan som kunskapsförmedlare, edited by Jan Peterson, 137-151. Stockholm: Prisma, 1979.

Liedman, Sven-Eric. "Folkpartiets skolpolitik." skolaochsamhalle.se. August 242014.

Lindensjö, Bo and Ulf P. Lundgren. Utbildningsreformer och politisk styrning. Stockholm: HLS förlag, 2000.

LOVUX IV: LO:s arbetsgrupp för vuxenutbildningsfrågor, "Utbildning för arbete och demokrati: rapport till LO-kongressen 1976." Stockholm: Prisma i samarbete med Landsorganisationen i Sverige, 1976.

Mahieu, Ron. Agents of Change and Policies of Scale. Umeå: Umeå University, 2006.

Mogård, Britt and Mona Sahlin. Skolan: Ett hett debattämne $i$ alla tider. Sveriges Radio's archive. October 3, 1978.

Motion 1983/84:2016.

Nilsson, Torbjörn. Moderaterna, marknaden och makten: Svensk högerpolitik under avregleringens tid, 1976-1991. Stockholm: Södertörns högskola, 2003.

Nordenbo, Sven Erik. "Bildung and the Thinking of Bildung," Journal of Philosophy of Education 36, no. 3 (2002), 341-52

Peterson, Jan, ed. Skolan som kunskapsförmedlare. Stockholm: Prisma, 1979.

Prop 1975/76:39. Skolans inre arbete.

Prop 1990/91:18. Om ansvaret för skolan.

Prop 1983/84:166, statement 97.

Richardson, Gunnar. Svensk utbildningshistoria. Lund: Studentlitteratur, 2010.

Ringarp, Johanna. "From Bildung to Entrepreneurship: Trends in Educational Policy in Sweden", Policy Futures in Education 11, no. 2 (2013), 456-64.

Rudvall, Göte ed. Bildning och utbildning: Texter till ett seminarium om bildning och utbildning, Malmö: Lärarhögskolan, 1994. 
Ruin, Hans and Maria Sà Cavalcante Schuback. Bildning och filosofi. Stockholm: Högskoleverket, 2006.

Skoglund, Crister. "Herder och en skola för bildning." Forskning om utbildning 3, no. 4 (1993), 16-29.

SOU 1974:53: Skolans arbetsmiljö. Stockholm: Allmänna förlaget, 1974.

SOU 1977:09 Betygen i skolan. Stockholm: Allmänna bokförlaget, 1977.

SOU 1992:94: Skola för bildning. Stockholm: Allmänna förlaget, 1992.

Sparn, Walter. "Religiöse und theologische Aspekte der Bildungsgeschichte im Zeitalter der Aufklärung." In Handbuch der Deutschen Bildungsgeschichte. Band II. Vom späten 17. Jahrhundert bis zur Neuordnung Deutschlands um 1800, edited by Notker Hammerstein and Ulrich Herrmann. München: Beck, 2005.

Sundgren, Gunnar. Bildning och utbildning: En akademi för bildning? Stockholm: Högskoleverket, 2008.

Svensson, Lennart. Från bildning till utbildning: del 1. Göteborg: Sociologiska institutionen, Göteborgs universitet, 1978.

Wedin, Tomas. "Ideological Continuity and Discursive Changes in the Swedish Educational System." LIR. Journal, no. 3 (2013), 49-65.

Wiklund, Matilda. Kunskapens fanbärare: Den goda läraren som diskursiv konstruktion på en mediearena. Örebro: Örebro universitet, 2006.

Äpplets skriftserie. Strängnäs: AKS, 1980-1983.

Äpplet. Strängnäs: Kunskapsrörelsen-AKS, 1981-1991.

Östling, Johan. Nazismens sensmoral: Svenska erfarenheter i andra världskrigets efterdyning. Stockholm: Atlantis, 2008. 